\title{
Hikayat Sang Kancil and Buaya: an Interactive Animation
}

\author{
Norfarizah Mohd Bakhir \\ School of the Arts, \\ Universiti Sains Malaysia \\ Pulau Pinang, Malaysia \\ farizah@usm.my
}

\author{
Julina Ismail@Kamal \\ School of the Arts, \\ Universiti Sains Malaysia \\ Pulau Pinang, Malaysia \\ julina@usm.my
}

\author{
Nurliana Yusri \\ School of the Arts, \\ Universiti Sains Malaysia \\ Pulau Pinang, Malaysia \\ nurlianayus@gmail.com
}

\begin{abstract}
This research attempts to provide a platform to help sustain Malay folklore that is forgotten over time. Thus, an interactive 2D animation about the Tale of Mousedeer and Crocodile or 'Hikayat Sang Kancil \& Buaya' was proposed as a new alternative of folklore storytelling to enhance user experience. There are three main objectives in this study. Firstly, to identify the main factors contributing to the abandoning of the Malay folklore. Secondly, to analyse the existing tools and media available related to sustaining Malay folklore. Lastly, to design an interactive animation to help sustain Malay folklore by adapting it into the modern world through technology. The research methods used in this research were both qualitative and quantitative, to help obtain information, opinions, and ideas related to the research from the view of professionals from various backgrounds. The technology used is motion sensor technology using Leap Motion Controller to enable the interactivity between the animation and the user. The outcomes from this study shows that the respondents enjoy this new platform for Malay folklore storytelling. As a conclusion, this research helps to sustain the Malay folklore from the being swallowed by the modernization.
\end{abstract}

Keywords: Folklore; Digital Storytelling; Interactive Animation; Leap Motion Controller

\section{INTRODUCTION}

Malay folklore consists of folk music and song, bardic tales, animal fables, ghost stories, epics, fairy tales, symbolic lore and myth (Rahim, 2014a). It has been told for a long time ago and the stories were passed down from generation to generation (Rahim, Halim \& Mamat, 2014). During the time where folklore was known to many, it has given positive effects towards the growth of the younger generation in understanding good values of their ancestors (Rahim, 2014a). Usually, the elders will be telling the folk tales to the younger generation. As time passed, folk tales were no longer told and forgotten.

Folklore is a part of social activities among the Malay community. The 'Sang Kancil dan Buaya' (mousedeer and crocodile) and the 'Sang Kancil dan Monyet' (mousedeer and monkey) are among the popular folklore collections among the Malays in Malaysia (Mohd Bakhir, Bidin \& Nordin, 2017). In an animal-based story, animals are simply used as tools for developing stories that are actually aimed at sarcasm and as metaphor concerning the human beings themselves. The animal fable reflects the true story of human life and is a major aspect of the thought that is delivered by an author or anonymous narrator a long time ago (Mamat Mustafa \& Md Ali, 2017). Although, animal fables such as 'Hikayat Sang Kancil' have been adapted into animation several times, it is not being reminisced by the young generations. This is probably due to the stereotypical thoughts of animal fables as childish by the younger generation. However, we cannot solely blame at them for the thoughts that has been implanted into their minds. The way the stories about Sang Kancil or the mousedeer was told was commonly intended for the children. With the right methods, this perspective can be changed .

Malay folklore were much more popular among the folk during the time where there are no technologies. A rapid enhancement of technology has made Malay folklore less popular among the younger generation (Rahim, 2014a; Rahim, 2014b). Some of them may never even heard of 'Sang Kancil dan Kura-kura' (mousedeer and tortoise). It seems like Malay folk tales have been swallowed by modernization. Younger generation prefers playing modern games on their smartphones or laptop (Rahim, Affendi \& Pawi, 2017).

While technology may be the main reason for the unpopularity of Malay folklore, it may also be the way to bring it back to the modern world. Several studies have been conducted to bring back the forgotten folklore through the use of technology and multimedia (Rahim, 2014a; Abidin \& Razak, 2003; Rahim, Affendi \& Pawi, 2017; Rahim, Halim \& Mamat, 2014). However, most of the research focuses more on software development and the digitization of folklore content from hard copy to soft copy. There is lack of interactive application made for the purpose of sustaining the folklores. Thus, in order to bring back the forgotten folklore to this modern era, an interactive $2 \mathrm{D}$ animation is proposed to enhanced user experience towards Malay folklore. This animation allows user interaction during the storytelling process. This animation will only be focusing on only one folklore.

The selected folklore will be from 'Hikayat Sang Kancil'. There are many tales in 'Hikayat Sang Kancil' which include 'Sang Kancil and the Crocodiles', 'Sang Kancil and the Monkey', 'Sang Kancil and the Elephant', Sang Kancil and the Tiger', etc. This project will be focusing on one tales for a start. The tales that are chosen is 'Sang Kancil and the Crocodiles'.

The objectives of this project is to identify the main factor contributing to the forgotten of Malay folklore. Second is to analyse the existing tools and media available related to sustaining Malay folklore and thirdly is to design an interactive animation to help sustain Malay folklore by adapting it into the modern world through technology.

The 'Hikayat Sang Kancil' convey the message of a small, vulnerable-looking creature like a mousedeer capable of overcoming much larger and fiercer creatures by using its intelligence (Chew \& Ishak, 2010). For instance, in 'Sang Kancil and the Crocodiles', Sang Kancil perform some tricks on the crocodiles in order to cross the 
river. While in other stories of 'Sang Kancil' epic, 'Sang Kancil and the Monkey', for example, Sang Kancil was trying to warn the monkey of not consuming the chilies, however, ignored by the stubborn monkey. The earlier version of Malaysian animation entitled 'Hikayat Sang Kancil' was first produced in 1983 by Filem Negara Malaysia (FNM). The intention of this animation is to promote good deeds and convey the message of always cautious and vigilant towards the surrounding environment and the people around us (Harun \& Rahim, 2010).

A recent version of Sang Kancil tales was in 3D animation produced by Les' Copaque called 'Pada Zaman Dahulu' (2011 - 2013). Rambli, Matcha, Sulaiman \& Nayan (2012), designed and developed an interactive augmented reality (AR) edutainment storybook for the preschool based on one of the Sang Kancil folktales, 'Sang Kancil and the Crocodiles'. The AR storybook receives positive feedback from both parents and young children. The development of the AR storybook has brought the Sang Kancil folktales to a different platform.

The idea of designing an interactive animation about 'Hikayat Sang Kancil' seems appropriate and possible to be implemented as an initiative to help sustain Malay folklore. With the help of technological advances, the traditions and legacies should be brought along with modernity (Mohd Bakhir \& Abdullah, 2017). The length of an animation must be appropriate and not extremely long to avoid boredom by the audience (Vaněček, \& Jirsa, 2011). Jarboe (2012), in his articles, shows that the average length of the Top 10 most shared video of all time is less than 5 minutes. The expected benefit from this interactive animation is to promote local folktales to the younger generation as an act of cultural preservation.

\section{A. Animation}

Animation has come from a long way before it became like the one that we see today. Animation in context means a simulated motion that shows a series of images (Mohd Bakhir, Bidin \& Noorazidi, 2015). Baecker (1969) defined animation as 'the graphic art which occur in time'. Since the time of traditional animation, the character's or object's movement in a scene were drawn frame by frame and were arranged in sequence. Movement is the root of an animation. This root is held by the animators to translate 'motion' in plants, humans and animals in animations (Mohd Bakhir, Bidin \& Nordin, 2017). Similar concept was applied onto the modern animation which involves 3D environment whereby the character, camera and object movement were captured in key frames on a timeline. This series of graphics played in a timeline delivers information to the audience (Beacker, 1969). Animation exist in multiple forms such as moving text, objects, drawing and computer-generated images (CGI) (Mat Omar \& Ahmad Ishak, 2011).

Animation does not only restricted in the form of fullfledged animated films or series such as 'Upin \& Ipin' (2007 - present) and 'Boboiboy' (2011 - 2016) but also appear in the form of advertisement, video games and liveaction films. As we know, Hollywood film and American TV series often incorporate CGI and visual effects with reallife acting scenes using the techniques such as motion capture and green screen to achieve the perfect combination. Mat Omar \& Ahmad Ishak (2011) also state that Greenberg (2011) suggested that animation definition has become indistinct due to the way animation is applied.

\section{B. Interactive Animation}

Interactive animation is non-linear and the storytelling progression is not controlled by the animator (Dinç, n.d.). Tomlinson (2005) described the intelligence and behaviour of the characters in interactive animation are generated by a computer program in real-time. He further discussed that the character's decision making in an interactive animation may greatly affect by the user's emotion. Interactive animation is applied in various forms, including web and video games (Dinç, n.d.). The term interactive animation is a combination of the term 'interactive' and 'animation'. Interactive involve the transfer of information between two parties. In the perspective of technology, it could refer to the two-way communication between the human and the machine. Another term that is commonly used to describe the human and the machine interaction is Human-Computer Interaction (HCI). The basic human interaction occurs when information transfer is received and sent (Dix, Finlay, Abowd, \& Beale, 2004). Significantly, in HCI, there is a need for input and output as well. There are three senses out of five major human senses that involve in the HCI which are sight, hearing and touch (Dix, Finlay, Abowd, \& Beale, 2004).

Digital devices that involve interaction with these major senses have already made available in the market. He et al. (2017) classify the interaction pattern as voice, gesture, physical and visual. The intelligent voice recognition technology was first popularized by Apple Siri that integrates with iPhone's iOS. Siri is able to comprehend spoken commands, identify the conversation context and responds to questions in a friendly way (Geller, 2012). On the other hand, there are several popular digital devices that are capable of capturing user's gesture. Microsoft Kinect sensor, originally designed for enhancing user experience when playing games via Xbox console by enabling interaction between the game and player's body movement, has extended its usability beyond the gaming industry (Zhang, 2012). Another gesture interaction tool, Leap Motion Controller, is a fairly new device that is designed for capturing hand gesture and finger position in interactive application (Weichert, Bachmann, Rudak \& Fisseler, 2013). A study by Weichert, Backmann, Rudak \& Fisseler (2013), concludes that the Leap Motion Controller can achieve the accuracy up to $0.01 \mathrm{~mm}$ which is more precise compare to that of Kinect that can only achieve approximately $1.5 \mathrm{~cm}$ accuracy. Virtual Reality (VR) is a computer-generated environment that manipulated the user's mind by allowing them to immerse into the virtual world (Desai, Desai, Ajmera \& Mehta, 2014). Entering into the VR world is only possible through the vision from the VR headset. This technology applies the visual interaction pattern as mentioned earlier. Oculus Rift is one of the pioneer VR headset.

\section{The Story}

The storyline of the 'Hikayat Sang Kancil dan Buaya' is adapted from the earlier version of the story produced by Filem Negara Malaysia (FNM) in 1993 with the same title. According to Saputra (2009), adaptation can be made 
in three ways; based on entirely on the original text, based on the conflict of the original story or create a whole new story. In this study, adaptation was made by developing stories based on conflict. Through adaptation, part of the original story is added and dropped appropriately (Mohd. Nasir \& Bujang, 2015). The characteristics of the Sang Kancil were shown as a mischievous and intelligent animal that trick others to solve problems and to gain advantages for itself. At the same time, the character displays a selfish attitude. This particular attitude, in my opinion, is seen as inappropriate to be a role model for the younger generation. Therefore, certain scene that displays the selfishness will be dropped and replace with a better situation. The following text is the re-written storyline for the interactive animation:

A long time ago, there lived an intelligent mouse deer called the Sang Kancil. On one fine day, Sang Kancil went out to the woods to search for food. Across the river, there are many ripe fruits. Sang Kancil walks towards the riverbank to get a closer look on the water apples. Suddenly, a crocodile emerges from the water and launch an attack to Sang Kancil, attempting to bite him. Sang Kancil is fast enough to dodge the attack. Later, more of them appear from the water. The leader of the crocodile confronts Sang

Kancil. He said, "What are you doing in our territory? Are looking forward to be our meal?" The other crocodiles grinned. Knowing that his life in great danger, Kancil came out with a brilliant idea. "The king is organizing a banquet. Delicious food around the country will be served. His Highness has ordered me to count the number of crocodiles in the river." says the Kancil. Feeling suspicious, the crocodile leader replied, "How do we know that you are not lying to us?" With confidence, the Kancil replied, "Well, you can choose not to believe in me, but there will be no seat for you at the banquet if the king doesn't know how many of you will be attending. It's your call." Kancil's confidence and the desire to attend the banquet has made the crocodiles believe in the lies. With haste, the crocodile leaders command all of his underlings to line up. When all is ready, the Sang Kancil started counting the crocodiles by hopping from one crocodile to another until he reached to the other side of the river. Then, the crocodile leader asks,

"Well, you still haven't told us when the banquet is?" Sang Kancil giggled, "You have been fooled. There will be no banquet. I wanted to cross the river, but one of you was trying to eat me. So, I had to trick all of you in order to save my life." The crocodile was furious. Not only has he lost his face in front of his underlings, he will not be getting any delicious food. Sang Kancil walks away from the river towards the fruit trees and enjoy his meal.

\section{METHODOLOGY}

The research attempt to test the effectiveness of using technology to enhance the experience of Malay folklore such as Hikayat Sang Kancil storytelling. The research will determine whether this proposed method of Malay folklore storytelling through interactive animation is better than the traditional way such as reading books or verbal storytelling. Furthermore, the research will determine whether this new method will increase the interest among the younger generation towards Malay folklore. This research will use both survey and interview to collect the required data and information which is seen as appropriate to gather required information to achieve the research objective. The criteria of the subject that will test the effectiveness of the interactive animation in enhancing the Malay folklore storytelling are as follows and are selected to test the research objectives:

- Users are young adults between the ages of $20-35$ years old.

- Users that are interested to sustain Malay folklore.

- Users that are interested to see their childhood local folklore into an interactive animation.

An interview sessions are done as one of the data collection instrument for this research. The professionals from various backgrounds were interviewed. These people include Fariz Hanapiah, the Founder of Motiofixo Sdn. Bhd. Julina Ismail, senior lecturer of New Media Design \& Technology, USM and Adiguru or master craftsmen Che Mat Jusoh, Culture Artist, USM. The interview questions were aimed at stimulating relevant information concerning their opinion on the relevance of Malay folklore in this modern age and the attempt of digitizing it.

Questionnaires were also used in this research. The content of the instrument was targeted to the target audience. The questionnaire aims to collect data from the target audience on their demographics, their knowledge of Malay folklore and their understanding of the technology intended to use for the research. Questionnaires will be conducted several times at the different stage of the research. The first questionnaire is the pilot study to survey the possibility of the approach that is intended to use for the actual research (Leon, Davis \& Kraemer, 2011). The questions are about Malay folklore and interactive animation in general. The second questionnaire is more focused on the research scope.

It covers the respondent's knowledge and opinion on 'Hikayat Sang Kancil \& Buaya' and their familiarity with motion sensor technology. Finally, the third questionnaire is to collect feedback from the testing of the final product. In order to measure the effectiveness of the interactive animation, questions regarding the application will be asked in the questionnaire. Users are expected to provide some feedback based on their experience interacting with the application.

\section{ANALYSIS AND FINDINGS}

This chapter discusses the data analysis and findings from 100 respondents between 20-35 years old. The purpose of this study is to help sustain Malay folklore. As a solution, an interactive 2D animation is designed and developed as an alternative platform for Malay folklore storytelling. 2D animation is still relevant in this modern age and is one of the current trend of animation in terms of technique in Malaysia (Ismail, 2017). It is also agreed that the element of interactivity in the animation is able to enhance user experience on Malaysian folklore storytelling (Ismail, 2017). A modern and digital approach is used as an initiative to attract the younger generation towards the folklores.

The respondents' ages ranged from 19 to 35 , with the majority being $20-24(81 \%)$ respondents were at this age, followed by respondents between $25-30$ (14\%), 19 (4\%) 
and $31-35(1 \%)$. The target audience of this project are young adults between the ages of 20 to 35. Overall of the respondents matched the target audience

Are you familiar with the 'Hikayat Sang Kancil \& Buaya' before interacting with the animation?

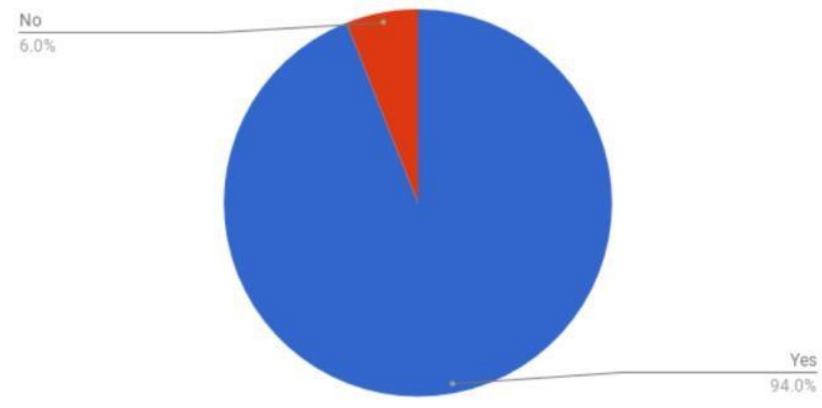

Figure 1. Respondents' Familiarity towards Hikayat Sang Kancil

Figure 1 reveal that of the 100 respondents, 94\% are familiar with 'Hikayat Sang Kancil \& Buaya' while the remaining $6 \%$ are not familiar. The high percentage of the ones who familiar shows that this folk tales are popular among the majority of the young adults. As mentioned by Mohd Bakhir, Bidin \& Nordin (2017) that 'Sang Kancil dan Buaya' are among the popular folklore collection in Malaysia

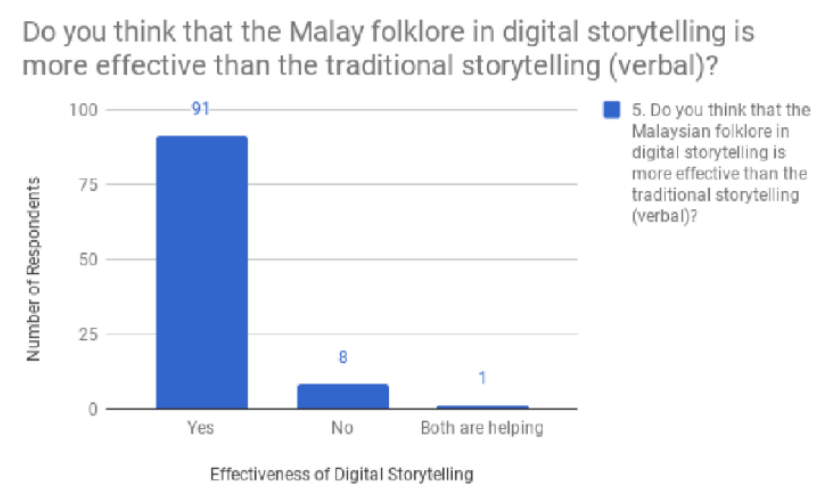

Figure 2. Effectiveness of Digital Storytelling

The result of the questionnaires in Figure 2 shows that $91 \%$ of the respondents agreed that Malaysian folklore in digital storytelling is more effective than the traditional storytelling which is often told verbally. The remaining $8 \%$ disagreed, followed by $1 \%$ who suggested that both versions, digital and traditional, are helping. As advised by Adiguru Che Mat bin Jusoh (2017), both digital and traditional storytelling should be told in parallel. According to him, traditional storytelling is our heritage, thus, it should not be forgotten. But at the same time, the traditional story can be adapted and improvise into digital version.

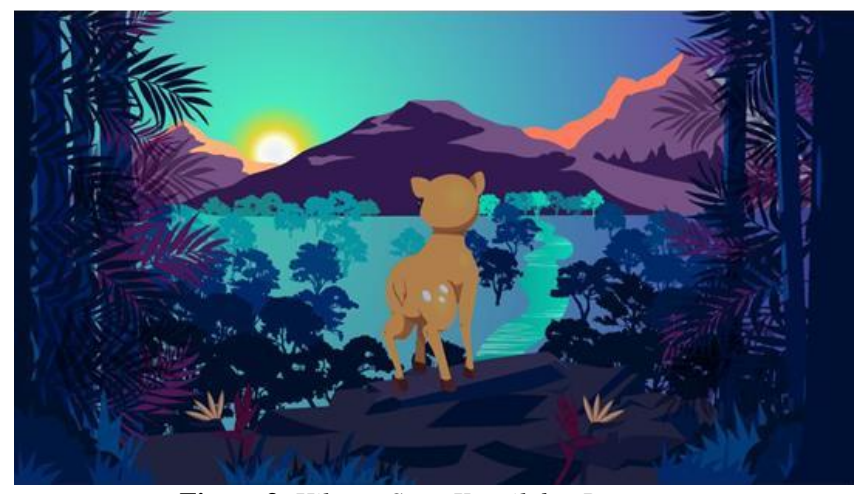

Figure 3. Hikayat Sang Kancil dan Buaya

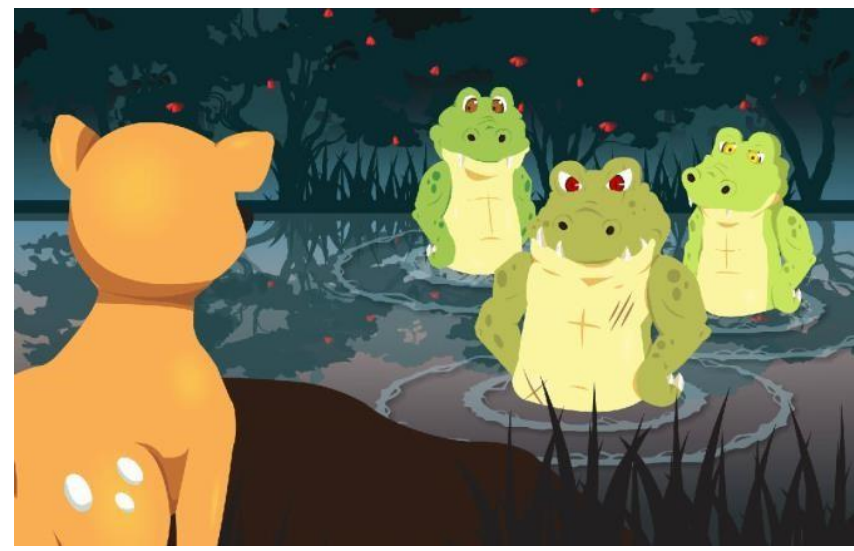

Figure 4. The Crocodiles

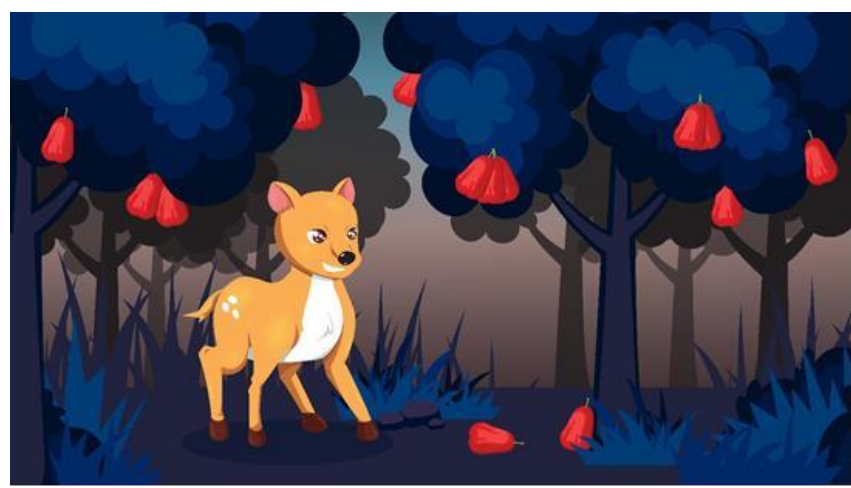

Figure 5. Across the river

The question regarding the ability to attract younger generation towards Malaysian folklore were asked whether this project will be able to attract younger generation towards Malaysian folklore. 99\% out of the 100 respondents agreed that this project will be able to attract younger generation towards Malaysian folklore, while the remaining $1 \%$ thinks that it maybe help. The respondent like the style that were used in the project. The colour used in the animation is mostly dark tones. Shades of black, blue and purple are used in the environment settings to give a darker feel to the surrounding environment. The idea of darker environment is to give a new look and feel to the 'Hikayat Sang Kancil \& Buaya'. However, brighter colour was applied to the characters to give them contrast to the environment as well as the highlight of the story.

The interaction device used in this project plays an important role in user interaction. The questions cover the user familiarity towards the device and their experience using the device. The animation comes with the element 
of interactivity to enhance user experience when engaging with the system. The interaction uses the Leap Motion Controller, a gesture detection device that is programmed to turn to the next scene when it detects the swipe gesture.

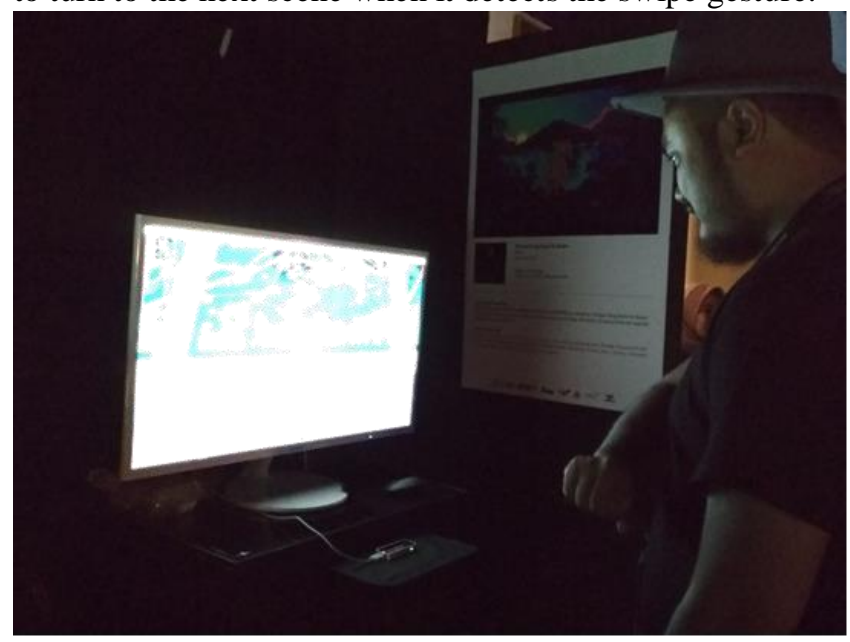

Figure 6. Leap motion controller swipe gestures

The user interaction with the animation uses Leap Motion Controller as the tool to store user input and send it to the animation to perform action. Adobe Flash CS6 does not contain a compatible library with Windows 10 to communicate directly with the Leap Motion Controller. Therefore, in order to overcome this problem, the Leap Motion Controller function is programmed in Processing 3 with Java as the language. User input from the Processing 3 side will be sent to ActionScript 3.0 Class in Adobe Flash CS6 via oscP5. Figure 4.10 shows the coding process of ActionScript 3.0 and Java side by side. There are several things that are observed when experimenting with Leap Motion:

- When the light is too bright, the Leap Motion will detect the light as infrared light, thus causes inaccuracy in the Leap Motion input. Yellowish light will cause the same thing as stated above happened.

- The swipe gesture must be made in a moderate speed. Too fast will leave the gesture undetected, too slow will make the device detects one swipe as several swipes.

- Leap Motion Controller has an interaction box, the detection area. It is located slightly above the device. When user's hand is too close to the device, it usually does not detect.

- User often mistook Leap Motion Controller as touch sensor rather than gesture sensor.

The Respondents' familiarity towards Leap Motion Controller were tested. Based on the result of the questionnaires, $26 \%$ of the respondents are familiar with the Leap Motion Controller. The remaining $74 \%$ of the respondents are not familiar with the device. The Leap Motion Controller is a fairly new device that is still unknown to most people. Although, this device has been around for quite some time, the publicity of this device is sparse. During the test, $60 \%$ of the respondents find it easy to control the device. An observation during the exhibition shows that the respondents are excited when they able to change the page on their first swipe. The remaining $40 \%$ of the respondents find it hard to control the device. Based on the observation, most unsuccessful swipe is contributed by either the wrongly positioned hand from the sensor. Occasionally, when the light is turned on, the sensor will have some sensitivity issue as the device detects the light as infrared light.

\section{CONCLUSION}

In conclusion, this project has managed to achieve all of the stated objectives. The first objective of the project is to identify the factors contributing to the forgotten of Malay folklore. This objective has been successfully achieved during the pilot study made at the initial stage of the project. The identification of the factors further strengthens with the interview done for the qualitative research. It can be concluded here that the extinction of Malay folklore is greatly contributed by the rapid growth of the technology. However, with technology itself, can help overcome this problem. Technology might distract people from the real thing, but with the right method, it can help to spread the ideas of folklore to the younger generation (Hanapiah, 2017). The second objective is to analyse the existing tools and media available to help sustain Malay folklore. There are not many platforms that offer interactive elements that related to Malay folklore. The third objective is to design an interactive animation to help sustain Malay folklore by adapting it into the modern world through technology. This refers to the proposed tool. According to the feedback received by the respondents and the findings of this research, the proposed tool is able to help sustain Malay folklore.

The tool is one of many solutions that can be used to help sustain Malay folklore. The tool is not a replacement of the traditional storytelling of Malay folklore, but an alternative to attract people of different preferences. The traditional form of folklore must be preserved because it is a heritage (Jusoh, 2017) while digital form can attract and promote to new generations with Malay folklore in different ways (Ismail, 2017). There are several recommendations from the respondents that can be done in order to improve this tool. One of the recommendation is to increase the sensitivity of the Leap Motion Controller. However, most of the respondents are not aware of the technical issues of this device. There is no inherent sensitivity of a swipe gesture of the Leap Motion Controller. The hand position and the swipe action play an important role in the detection to occur. The users often placed their hand too close to the sensor making it unable to detect their hands. Furthermore, this device is still a fairly new device. The instability of the device is known issue. Nevertheless, the interaction with the device excite the users at their first encounter. Some of them replay the animation just to play with the swipe gesture. Another recommendation is to include back feature that allows the user to go back to previous page. In the future, perhaps more folklore can be added to create a series of animation. This is also a suggestion from several respondents who demanded for more Malay folklore in this form. Another thing that can be done in the future is to make this tool into a portable application such as mobile app. This will allow the tool to be used anytime, anywhere.

This project attempts to provide a platform aim to help sustain Malay folklore that is forgotten over time. This platform will use the approach of using technology to attract the younger generation towards Malay folklore by 
designing a series of interactive motion graphics that tell the tales of local folklore. The expected benefit from this tool is the society will remember the forgotten folklore and perhaps enjoy the new approach.

\section{REFERENCES}

[1] Abidin, M. I. Z., \& Razak, A. A. (2003). Malay digital folklore: using multimedia to educate children through storytelling. Information Technology in Childhood Education Annual, 2003(1), 29-44J. Clerk Maxwell, A Treatise on Electricity and Magnetism, 3rd ed., vol. 2. Oxford: Clarendon, 1892, pp.68-73.

[2] Baecker, R. M. (1969, May). Picture-driven animation. In Proceedings of the May 14-16, 1969, spring joint computer conference (pp. 273-288). ACM.

[3] Chew, F. P., \& Ishak, Z. (2010). Malaysia folk literature in early childhood education.

[4] Dinç, N. (n.d). Traditional and interactive animation: from perspective of storytelling and production process. Retrieved from

Anadolu University Web site: http://newmedia.yeditepe.edu.tr/pdfs/isimd_06/06.pdfR.

Nicole, "Title of paper with only first word capitalized," J. Name Stand. Abbrev., in press.

[5] Dix A., Finlay J., Abowd G., \& Beale R. (2004). HumanComputer Interaction, 3rd edn. Upper Saddle River, NJ: Prentice Hall.

[6] Desai, P.R., Desai, P.N., Ajmera, K.D., Mehta, K., 2014. A Review Paper on Oculus Rift-A Virtual Reality Headset. arXiv preprint arXiv:1408.1173

[7] Geller, T. (2012). Talking to machines. Communications of the ACM, 55(4), 14-16.

[8] Greenberg, R. 2011. The animated text: Definition. Journal of Film and Video, Vol. 63, No. 2, pp. 3-10. DOI: 10.1353/jfv.2011.0009.

[9] Harun, A., \& Rahim, R. A. (2010, December). Analyzing the First Malaysian Animated Film "Hikayat Sang Kancil". In Science and

Social Research (CSSR), 2010 International Conference on (pp. 618623). IEEE

[10] Hanapiah, F. (2017, November 9). Personal interview.

[11] Ismail, J. (2017, November 12). Email interview.

[12] Jusoh, C. M. (2017, December 4). Personal interview.

[13] Leon, A. C., Davis, L. L., \& Kraemer, H. C. (2011). The Role and

Interpretation of Pilot Studies in Clinical Research. Journal of

Psychiatric Research, 45(5), 626-629. http://doi.org/10.1016/j.jpsychires.2010.10.008

[14] Mamat Mustaffa, M. \& Md Ali, R. (2015). Mencari Keakrifan Tempatana dari Teks ke Multimedia: Analisis Siri Sang Kancil.

Penerokaan Teknologi Melalui Seni dan Warisan dalam Keakrifan Tempatan, 11-28

[15] Mat Omar, M. A. \& Ahmad Ishak, M. S. (2011). Understanding Culture Through Animation: From the World to Malaysia. Malaysian Journal of Media Studies, 13(2), 1-9.

[16] Mohd Bakhir, N. \& Abdullah, M. C. (2017). Inovasi Penceritaan Wayang Kulit Kelantan melalui Kaedah Interaktif Digital. Warisan Keakrifan Tempatan: Pemeliharaan Melalui Teknologi. 50-61

[17] Mohd Bakhir, N., Bidin, M. O. \& Noorazidi, S. N. A. (2015). Holografi Reflektif Animasi Dua Dimensi Buku Cerita Dongeng Rakyat Tempatan Penerokaan Teknologi Melalui Seni dan Warisan dalam Keakrifan Tempatan, 3951.

[18] Mohd Bakhir, N., Bidin, M. O. \& Nordin, M. F. (2017). Teknologi Media Baharu: Satu Ekspresi dalam Memelihara
Cerita Rakyat Melayu. Warisan Keakrifan Tempatan: Pemeliharaan Melalui Teknologi, 61-69.

[19] Mohd. Nasir, N. Y. \& Bujang, R. (2015). Kajian Animasi: Pembangunan Cerita Bangsawan dalam Format Animasi Dua Dimensi. Penerokaan Teknologi Melalui Seni dan Warisan dalam Keakrifan Tempatan, 103-119

[20] Rahim, N.A. (2014a). The Nearly Forgotten Malay Folklore: Shall We Start with the Software? Turkish Online Journal of Educational Technology-TOJET, 13(3), 216221.

[21] Rahim, N. A. (2014b). Perception on the Animal Fable 'Bird of Paradise' Song. Asian Social Science, 10(19), 17.

[22] Rahim, N. A., Halim, H. A., \& Mamat, R. (2014). Awareness of Folklore in Multimedia: Spoken Discourse among Learners. Technics Technologies Education Management, 9(2), 352-360.

[23] Rambli, D. R. A., Matcha, W., Sulaiman, S., \& Nayan, M. Y. (2012). Design and development of an Interactive Augmented Reality edutainment storybook for preschool. IERI Procedia, 2, 802-807.

[24] Saputra, H. S. P. (2009). Transformasi lintas genre: Dari novel ke filem, dari filem ke novel. Humaniora, 21, 41-55.

[25] Vaněček, D., \& Jirsa, J. (2011). Electronic education. Acta Polytechnica, 51(3).

[26] Weichert, F., Bachmann, D., Rudak, B., \& Fisseler, D. (2013). Analysis of the accuracy and robustness of the leap motion controller. Sensors, 13(5), 6380-6393.

[27] Zhang, Z. (2012). Microsoft kinect sensor and its effect. IEEE multimedia, 19(2), 4-10. 